\title{
Strategy of Advertising Tax Collection in the Digitalization Era on Badan Pendapatan Daerah of DKI Jakarta
}

\author{
Eka Rofiyanti ${ }^{1}$, Ika Muji Lestari ${ }^{2}$, Istamkhuja Olimovich Davronov ${ }^{3}$, \\ Alian Natision ${ }^{4}$, Krishantoro ${ }^{5}$ \\ ${ }^{1245}$ Institut Ilmu Sosial dan Manajemen STIAMI, Indonesia \\ ${ }^{3}$ Bukhara State University, Uzbekistan \\ Correspondent: rofiyanti.ekasumarno@gmail.com ${ }^{1}$
}

$\begin{array}{ll}\text { Received } & \text { : August 26, } 2021 \\ \text { Accepted } & \text { : January 15, } 2022 \\ \text { Published } & \text { : January 31, } 2022\end{array}$

Citation: Rofiyanti, E., Lestari, I, M., Davronov, I, O., Natision, A., Krishantoro (2022). Strategy of Advertising Tax Collection in the Digitalization Era on Badan Pendapatan Daerah of DKI Jakarta. Ilomata International Journal of Tax \& Accounting.3(1), 46-56. https://doi.org/10.52728/ijtc.v4i1.421
ABSTRACT: The phenomenon of this research is that in the digital era, many people switch to promoting their products to social media, which is one of the causes of the decrease in billboard taxes. This study aims to find out the right strategy in the billboard tax collection in the digital era by the Regional Revenue Agency of DKI Jakarta. The research method used is the descriptive qualitative method. Data sources include primary data, namely data from interviews, and secondary data, namely target data and billboard tax realization from 2016-2020. The results of this study indicate that (1) The billboard tax collection strategy in the digitalization era in the future will lead to billboard data collection, optimization of billboard objects and tax applications such as e-tax (2) the power of billboard taxes in the digital era lies in the development of digital technology and cooperation between the government, the private sector and the community; and (3) obstacles and challenges from billboard taxes in the digitalization era are the number of taxpayers who have not mastered technology and are not obedient in paying their tax obligations. The suggestion in this study is that the Regional Revenue Agency of DKI Jakarta forms a fieldwork team to conduct more thorough data collection, take advantage of technological developments, lead the comprehensive campaign to taxpayers, and provide strict sanctions to taxpayers who do not obey and install illegal billboards and (3) obstacles and challenges from billboard taxes in the digitalization era are the number of taxpayers who have not mastered technology and are not obedient in paying their tax obligations. The suggestion in this study is that the Regional Revenue Agency of DKI Jakarta forms a fieldwork team to conduct more thorough data collection, take advantage of technological developments, lead the comprehensive campaign to taxpayers, and provide strict sanctions to taxpayers who do not obey and install illegal billboards and (3) obstacles and challenges from billboard taxes in the digitalization era are the number of taxpayers who have not mastered technology and are not obedient in paying their tax obligations. The suggestion in this study is that the Regional Revenue Agency of DKI Jakarta form a fieldwork team to conduct more thorough data collection, take advantage of technological developments, work a comprehensive campaign to taxpayers, and provide strict sanctions to taxpayers who do not obey and install illegal billboards.

Keywords: tax collection, billboard tax, digital era. 


\section{Strategy of Advertising Tax Collection in the Digitalization Era on Badan Pendapatan Daerah of DKI Jakarta \\ Rofiyanti, Lestari, Davronov, Natision, Krishantoro}

\section{INTRODUCTION}

DKI Jakarta is the capital city of Indonesia which is the center of development. Therefore, it creates many business opportunities and causes for many investors or entrepreneurs to open a business in Jakarta (Hadi, 2021). Then indirectly increases tax revenues, especially advertisement taxes, because the more people who own companies or industries, the more consumers use billboard services (Dewanti, 2021). The number of companies influences the advertisement tax revenue to develop to promote their products, both small, medium and large businesses in Jakarta (Safitri, 2021).

Advertising tax itself is a tool used as a bridge between producers and consumers to introduce products produced by companies or other functions with the same purpose (Konfino et al., 2015). Because the billboard tax is located at strategic points and is widely accessible by the public, billboards are one of the most appropriate media to promote products to the public (Koumpias \& Martinez-Vazquez, 2019). Besides billboards, they can be in the form of boards, advertising advertisements, such as newspapers, magazines, etc., and electronic media such as television, radio, and social media (Cyan et al., 2017).

Digitization is an era transformation from analog mechanical and electronic technology to digital technology that has occurred since 1980 and continues to this day (Flach et al., 2021). Along with the times, digital technology continues to change for the better (Bellofatto \& Besfamille, 2021). Many people have used digital technology in various fields of life, including in the field of taxation. In the current era of digitalization, the installation of billboards has been widely used and utilized by social media (Seip, 2019). For example, on Instagram, Facebook, YouTube, and other social media. This is one of the reasons why it is rare to find billboards installed on giant billboards. So often saw large billboards that are empty or not filled with advertisements (Alsukait et al., 2020; Song et al., 2020).

To anticipate this, the DKI Jakarta Regional Revenue Agency (Bapenda) continues to look for solutions and strategies to increase advertisement tax revenues in the digitalization era Lidyawati, 2021). One of them is by supporting the installation of advertisements in the form of electronics or LEDs to attract more consumers (Octaviany et al., 2021). However, this solution and strategy from the DKI Jakarta Bapenda have not yet impacted the billboard tax revenue at the DKI Jakarta Bapenda. We can see this from the advertising tax target data in 2020 derived from 2019 (Dewanti, 2021). Therefore, based on this phenomenon, the researchers are interested in further researching the advertisement tax, which the author puts into the thesis entitled "Analysis of Advertising Tax Collection Strategies in the Era Digitization at the DKI Jakarta Regional Revenue Agency 2021."

\section{METHOD}

This study used the descriptive qualitative method (Moleong, 2018). Through this approach, researchers can introduce subjects and feel what they experience in their daily lives (Bungin, 2017). And can perform an analysis of events, phenomena or social circumstances (Creswell, 2017). The concept in this study is to analyze the Advertising Tax Collection Strategy in the Digital era carried out by the DKI Jakarta Regional Tax Revenue Agency. Data collection techniques were carried out through observation and continued with collecting relevant data (Sugiyono, 2019). Furthermore, the researcher conducted interviews with the DKI Jakarta Regional Tax Revenue Agency and academics to strengthen the information and data obtained (Mardiasmo, 2016). 
Strategy of Advertising Tax Collection in the Digitalization Era on Badan Pendapatan Daerah of DKI Jakarta

Rofiyanti, Lestari, Davronov, Natision, Krishantoro

\section{RESULT AND DISCUSSION}

\section{Advertising tax collection strategy in the digitalization era at the DKI Jakarta Regional Revenue Agency.}

One of the local revenue sources (PAD) is the advertisement tax (Muhaimin et al., 2019). The advertisement tax itself is a tool that connects producers and consumers to introduce products produced by companies (Hasibuan, 2020). Because of the strategic location of the billboard and it can be seen by many people, the billboard becomes one of the right tools to introduce and promote a product to the public (Bahmid \& Wahyudi, 2018). Besides being in the form of billboards, it can also be in the form of boards, advertising advertisements such as newspapers, magazines and others, and electronic media such as television, radio, and social media (Neni et al., 2021).

Based on sources from the Regional Revenue Agency or Bapenda DKI Jakarta with various types of billboards that can be used to introduce goods and services in the administration of billboards, there are multiple forms of irregularities in the administration of billboards (Lidyawati, 2021). The number of advertisements installed is a great opportunity for local tax revenues Rolamdo \& Widiastuti, 2021). Before entering the digital era at the DKI Jakarta Bapenda, the income or realization of the advertisement tax did not reach the target because there were illegal advertisements such as unlicensed advertisements and did not extend the period of the advertisement administration (Karo et al., 2019). But after entering the digital age, many companies prefer to promote their products using digital or social media because they are considered more effective and efficient (Hanis \& Saputra, 2019). The digital footprint will never be lost or erased even though the times have changed. And this has become a phenomenon at this time (Anggreni et al., 2020). Currently, Bapenda DKI Jakarta must have a good strategy so that the advertisement tax can continue to reach its target. Because in the current digitalization era, people or entrepreneurs prefer to post their advertisements through social media because they can be seen by everyone anywhere and anytime and will not be erased even though the times have changed (Mulatsih et al., 2021).

Bapenda DKI Jakarta continues to look for strategies to increase advertisement tax revenues by collecting advertisement data, both licensed advertisements and have extended the implementation of ads and advertisements that are not approved and have not developed the implementation of advertisements (Ratnaningsih \& Waluyo, 2019). Also, the DKI Jakarta Bapenda is revising the old governor's regulation, namely the Governor's Regulation of the Special Capital Region of Jakarta Number 148 of 2017 concerning Instructions for Implementing Advertisements which replaces Advertisement Rent Value (NSR) into contract value because it is considered more rational in setting the price of billboards. In addition to collecting data, the DKI Jakarta Regional Revenue Agency is also optimizing the implementation of LED billboards because they are considered an opportunity to increase billboard tax revenues in the digitalization era (Wulandari et al., 2017). This optimization is carried out by expanding the installation of LED billboards such as in boxcars in remote areas, at public transportation waiting for regions such as the MRT and in crowded areas such as the Thamrin area Central Jakarta. Then in terms of UPPPD, it is also improving the quality of service by utilizing the current progress and development of information and communication technology to provide the best service to billboard taxpayers (Muspirawati et al., 2021). 


\section{Strategy of Advertising Tax Collection in the Digitalization Era on Badan Pendapatan Daerah of DKI Jakarta}

Rofiyanti, Lestari, Davronov, Natision, Krishantoro

The following is a discussion regarding the six elements in formulating strategy according to the theory of Stephen P. Robbins \& Mary Coulter, namely:

a. External Environmental Analysis

External environmental analysis is a step taken to identify things of interest to the community and affect life in the present and the future. To analyze the external environment can be done in several ways, including:

1) They optimize LED billboards and other types of billboards and develop potential objects for advertising taxes such as LED billboards, which still have considerable potential in increasing advertising tax revenue in the digitalization era. This is because LED technological developments will assist in future billboards.

2) Continue to race against the Law on Regional Taxes and Regional Levies, namely Law Number 28 of 2009 wherein the Law explains the definition of regional taxes and levies, types of regional taxes in which there is an advertisement tax and explains the object and subject of the advertisement tax itself, what which is not included in the advertisement tax, the basis for the imposition of the advertisement tax, the advertisement tax rate and the principal amount of the advertisement tax.

3) Keeping up with technological advances to provide the best service to advertisement taxpayers

4) Involvement of advertisement taxpayer participation. The participation of the billboard taxpayer can increase the awareness of taxpayers in paying their taxes through the participation of billboard taxpayers it is hoped that it will increase the awareness and compliance of taxpayers in paying their tax obligations.

5) Socialization and counseling to billboard taxpayers to increase public awareness and collect data for non-taxpayers or unlicensed billboards and analyze taxpayers' perceptions of the billboard tax.

6) Reviewing the strategies used to achieve an increase in revenue from advertising tax

b. Internal Environmental Analysis

Internal environmental analysis is a step that can be taken in formulating strategies by identifying the resources owned by both human and financial resources to support the strategy made. An internal environmental analysis can be done through:

1) Conducting data collection starts from collecting data on empty and filled points to optimize billboard acceptance. And also attracts many graduates in the field of statistics to collect data. As well as conducting data collection to measure the potential for advertising taxes.

2) Provide convenience in service to taxpayers.

3) Strengthening internal consolidation, such as enhancing human resources, whether they can carry out the strategic system used or whether financial resources are sufficient to support the implemented strategy system. And also have to improve the existing bureaucracy.

4) Building a good and accurate data system, providing rewards and punishments for obedient and disobedient taxpayers as a form of law enforcement.

5) Must review the strategies used to achieve increased revenue from advertising tax.

c. Strategy Formulation 
Strategy of Advertising Tax Collection in the Digitalization Era on Badan Pendapatan Daerah of DKI Jakarta

Rofiyanti, Lestari, Davronov, Natision, Krishantoro

Strategy formulation is a way to formulate a strategy that will be made by making an effective and efficient long-term plan. The formulation of formulating strategy tends to collect data and extensification advertisements. Because if you look at the 2016-2020 billboard tax target and realization table, where the target and realization data are fluctuating, the trend of the percentage of tax revenue is positive. However, if we look at the target size, it can be seen that there is a reduction in the target so that the realization has increased.

Table 3.1

Target and Realization of DKI Jakarta Advertisement Tax 2016-2020

\begin{tabular}{|l|l|l|c|}
\hline Year & \multicolumn{1}{|c|}{ Target } & \multicolumn{1}{|c|}{ Realization } & Percentage \\
\hline 2016 & $\mathbf{1 , 1 5 0 , 0 0 0 , 0 0 0 , 0 0 0 , 0 0 0}$ & $\mathbf{8 9 4 , 2 7 1 , 3 3 1 , 5 9 1}$ & $\mathbf{7 8 \%}$ \\
\hline 2017 & $\mathbf{8 5 0 , 0 0 0 , 0 0 0 , 0 0 0}$ & $\mathbf{9 5 5 , 5 7 8 , 7 5 7 , 4 8 5}$ & $\mathbf{1 1 2 \%}$ \\
\hline 2018 & $\mathbf{1 , 1 5 0 , 0 0 0 , 0 0 0 , 0 0 0 , 0 0 0}$ & $\mathbf{1 . 0 2 0 , 0 0 0 , 0 0 0 , 0 0 0}$ & $\mathbf{8 9 \%}$ \\
\hline 2019 & $\mathbf{1 , 0 5 0 , 0 0 0 , 0 0 0 , 0 0 0}$ & $\mathbf{1 , 0 7 9 , 4 9 2 , 8 0 2 , 7 0 1}$ & $\mathbf{1 0 3 \%}$ \\
\hline 2020 & $\mathbf{7 7 5 , 0 0 0 , 0 0 0 , 0 0 0}$ & $\mathbf{8 2 7 , 4 8 4 , 4 0 1 , 2 0 5}$ & $106.77 \%$ \\
\hline
\end{tabular}

Source: DKI Jakarta Regional Revenue Agency

Based on this, the DKI Jakarta Bapenda must always carry out data collection, both data collection on billboard points so that it can collect data on advertisements that are licensed and not. To give strict sanctions to billboard taxpayers who do not have a permit and do not extend the implementation of billboards.

Formulating a strategy can also be done by forming an organization. So the organization is created and divided for those whose technical implementation is carried out by the UPPPD. At UPPPD they collect data, every time there is a new object, regional monitoring and supervision is carried out at UPPPD. The strategy is made in stages to not overlap with authority. The order in formulating the strategy itself is at the lowest technical level, supervision, and policy. Formulating the strategy is carried out based on policy instruments in the form of Governor's Regulations, Governor's Instructions, Decisions of the Head of the Agency \& Instructions of the Head of the Agency. The special strategy is carried out by each Head of the Regional Tax Collection Service Unit (UPPPD) at the Regional and Sub-District Levels according to the characteristics of their respective regions.

Building a work team or organization can also formulate strategies and is useful for recording and monitoring billboard points following policy instruments. The work team here starts from technical, then supervision and then policy. Each unit has its own obligations and does the work according to what is set with this work team.

\section{d. $\quad$ Setting Strategy}

Setting a strategy is a step to choose a strategy that will be implemented to the public or the community adjusted to the goals set, both long-term and short-term goals. To determine the strategy can be done by preparing a budget, adequate facilities and infrastructure or accommodating to support the strategy to be selected so as not to hinder the strategy's performance from being implemented. With this budget, facilities and infrastructure, of course, it must be able to provide the best service to billboard taxpayers. 


\section{Strategy of Advertising Tax Collection in the Digitalization Era on Badan Pendapatan Daerah of DKI Jakarta}

Rofiyanti, Lestari, Davronov, Natision, Krishantoro

\section{e. Implementing Strategy}

Implementing the strategy is the next step after setting the strategy. After a strategy has been established, the strategy must be implemented so that the public can judge the good and the bad of the strategy. Tax potential analysis can be done by optimizing LED billboards because LED billboards in the digitalization era have considerable potential in increasing the advertisement tax so that they must be increased again. In contrast, the weakness of LED billboards is the difficulty of finding transaction price information because the bureau tends to cover it up. Implementing the LED advertising strategy in the future will be an effective means to promote its products because people use digital more, but LED advertisements also have a weakness: the implementation of advertisements requires a large and crowded place.

Implementing a strategy using LED billboards has the opportunity because it can display several advertising products, attract the attention of potential consumers and be more communicative within a certain period. Implementing the DKI Jakarta Bapenda strategy has challenges in the form of the ability of taxpayers to master Information and Communication Technology (ICT) and how to socialize it. And there are still many tax officers who have to do more training. However, Bapenda DKI Jakarta also has a great opportunity to increase advertisement tax revenue in the digitalization era with the development of this technology. In implementing the DKI Jakarta Bapenda strategy, it is necessary to socialize and give strict warnings or punishments to stubborn taxpayers. Meanwhile, DKI Jakarta Bapenda's opportunity to implement the strategy is to collaborate between the government, the private sector, and the community to increase billboard taxes in the digitalization era. Implementing the Bapenda strategy has challenges in the form of the ability of taxpayers to use technology, then the opportunity from Bapenda DKI Jakarta in implementing the strategy is by utilizing technological developments to create strategies that can make it easier for taxpayers to pay their taxes.

\section{f. Strategy Evaluation}

Strategy evaluation is after the strategy is implemented, the strategy must be evaluated to see the feasibility of the implemented strategy. And if there is a shortage, a solution can be found. Evaluating the strategy, namely by expanding or intensifying the advertisement tax (such as LED billboards using boxcars in the regions), revising the old governor's regulations by changing the Advertisement Rental Value (NSR) into a contract value, because using the NSR is too large according to their transaction price and conducting a census namely to record existing points, which are empty or those that have not registered but also those that are obedient, meaning there are and pay.

Evaluating the strategy by collecting data in the field to control or see the potential that may still be withdrawn from the advertisement tax itself and collecting data on new objects and objects that have not been extended. Then send a letter to remind billboard taxpayers who do not comply. Evaluating the strategy can be done by improving the quality of service to Advertisement Taxpayers so that they get easier, cheaper, faster and more accurate services by utilizing information technology. Evaluating the strategy can be done by following the development of Information and Communication Technology (ICT). Because with the development of Information and Communication Technology, it can be used to create an effective and efficient strategy in collecting advertisement taxes in the era of digitalization. And with the convenience of 
technology, it can help billboard taxpayers pay their taxes because there is no need to come directly to the tax office and pay billboard taxes anywhere and anytime. Evaluating the strategy can be done by making laws or regulations that stipulate non-taxpayers or unlicensed taxpayers so that they do not lose the potential of the advertisement tax and need to collaborate with the central government and make flexible strategies so that it can make it easier for taxpayers to report their taxes.

2. Strengths and opportunities of the advertising tax collection strategy in the digitalization era at the DKI Jakarta Regional Revenue Agency.

a. The strengths and opportunities that the DKI Jakarta Bapenda has in setting a strategy for collecting billboard taxes in the digitalization era are the existence of technological developments or ICT developments that can help create software, for example, the reality of e-tax. Then according to Mr. Wahyu as a taxpayer and build collaboration that provides mutual benefits between the government, the private sector and the community

b. The strengths and opportunities of LED billboards to increase advertisement tax revenues are that LED advertisements have a great chance to increase advertisement tax revenues in the digitalization era, so they must be optimized. This is because LED billboards can be the right means to promote a product in the future. After all, people use digital more and also LED billboards are dynamic and can display several advertising products, thus attracting more public attention.

c. Strengths and opportunities in implementing advertising tax collection strategies in the era of digitalization. There is a great opportunity in the development and advancement of information and communication technology because it can be used as a means of making effective and efficient strategies in collecting billboard taxes, the strategy in question is like the existing tax application, namely e-SPT with this tax application, of course, it can make it easier for mandatory advertisement tax in carrying out its tax obligations. Strengths and opportunities in implementing the billboard tax collection strategy in the digitalization era can also be done through collaboration between the government, the private sector and the community to increase billboard taxes in the digitalization era and provide convenience for billboard taxpayers.

d. Strengths and opportunities in evaluating advertising tax collection strategies in the digitalization era, namely the development of information and communication technology that continues to experience renewal must be utilized to improve the billboard tax collection system or strategy. This technological advancement can be used to create a system or application that makes it easier for the public to pay billboard taxes. And an application can also be made that provides information to taxpayers such as information about which places can be used to place billboards. There is currently an e-tax application that can make it easier for taxpayers to pay or report their tax obligations.

3. Weaknesses and challenges of the billboard tax collection strategy in the digitalization era at the DKI Jakarta Regional Revenue Agency.

a. Weaknesses and challenges in setting advertising tax collection strategies in the digitalization era are the lack of openness, awareness and compliance of billboard taxpayers in reporting their tax obligations. Weaknesses and challenges in setting a strategy for collecting billboard taxes in the digitalization era at Bapenda DKI Jakarta, 
namely the lack of socialization regarding the importance of paying billboard taxes and firm action against billboard taxpayers who disobey and there is no easy access to any platform or e-com. Many people who have a lot of followers on social media can easily advertise their products on their social media. Weaknesses and challenges in determining the billboard tax collection strategy in the digitalization era at Bapenda DKI Jakarta, namely many people or even entrepreneurs who advertise their products on social media because they are considered cost-saving and will not be erased.

b. The weakness and challenge of LED billboards in increasing advertising tax revenue in the digitalization era is the difficulty of finding information related to transaction prices because many bureaus tend to cover transaction prices. So it is difficult for DKI Jakarta Bapenda to get the actual transaction price. The weakness and challenge of LED billboards in increasing billboard tax revenue in the era of digitalization are that the installation of billboards requires a large area and a crowded area and cannot be haphazardly placed because it requires electricity. To increase billboard tax revenue in the digitalization era, namely the lack of supervision and procedures in the development and extension of billboards so that illegal billboards are still rampant or without official permission from the DKI Jakarta Bapenda.

c. Weaknesses and challenges in implementing the billboard tax collection strategy in the digitalization era, the lack of ability of billboard taxpayers in using Information and Communication Technology and the lack of socialization from tax officials to billboard taxpayers. So that no matter how sophisticated the application that has been used in the field of taxation, there are still many taxpayers who have not been able to use technology, it will not work well. So it is necessary to carry out thorough socialization so that the system used can run well. Then the weakness in implementing the strategy also lies in the weakness of rules or warnings for billboard taxpayers who do not obey reporting or paying their tax obligations.

d. Weaknesses and challenges in evaluating advertising tax collection strategies in the digitalization era are stubborn billboard taxpayers, meaning that many billboard taxpayers organize unlicensed billboards. However, the DKI Jakarta Regional Revenue Agency has taken firm action against billboard taxpayers who do not comply with this kind of tax, namely, for billboard taxpayers who have registered, have paid and are licensed, they are given a letter later for taxpayers who the DKI Jakarta Regional Revenue Agency does not authorize. Collaborate with Satpol PP to reduce the billboards.

e. Weaknesses and challenges in evaluating the billboard tax collection strategy in the digitalization era at the DKI Jakarta Bapenda, namely with the existence of covid-19 that has existed in Indonesia since 2020, the central government has issued restrictions on outside activities, therefore currently field officers are limited, this causes services to taxpayers are also slightly reduced. The weakness and challenge in evaluating the billboard tax collection strategy in the digitalization era at Bapenda DKI Jakarta are that taxpayers often forget to pay their Advertising Tax obligations or divert the funds already available to pay taxes to be used to finance other needs that they think are more priority. A notification letter regarding the billing tax will be issued to overcome this. 


\section{Strategy of Advertising Tax Collection in the Digitalization Era on Badan Pendapatan Daerah of DKI Jakarta}

Rofiyanti, Lestari, Davronov, Natision, Krishantoro

\section{CONCLUSION}

The strategy for collecting billboard taxes in the digitalization era in the future will focus more on collecting data on licensed and unlicensed billboards and collecting data on advertisements that have been extended or not. The DKI Jakarta Bapenda also continues to expand the advertisement tax and revise the old Pergub by changing the NSR to the contract value because it is considered more able to adjust the price of advertisements. In addition to these strategies, the strategy in the digitalization era is to optimize the object of the advertisement tax, such as the current billboard running on boxcars and the creation of tax applications such as e-tax.

\section{REFERENCE}

Alsukait, R., Bleich, S., Wilde, P., Singh, G., \& Folta, S. (2020). Sugary drink excise tax policy process and implementation: Case study from Saudi Arabia. Food Policy, 90, 101789. https://doi.org/10.1016/j.foodpol.2019.101789

Anggreni, I., Sari, N. L. P. R., \& Mediatrix, M. (2020). Analisis Potensi dan Efektivitas Pemungutan Pajak Restoran Terhadap Realisasi Penerimaan Pajak Restoran Di Kecamatan Kuta Selatan. E-Jurnal Akuntansi, 30(3), 652. https://doi.org/10.24843/EJA.2020.v30.i03.p08

Bahmid, N. S., \& Wahyudi, H. (2018). Pengaruh Pemungutan Pajak Hotel dan Pajak Hiburan Terhadap Peningkatan Pendapatan Asli Daerah Kota Medan. Jurnal Riset Akuntansi Dan Bisnis, 18(1), 14-26. https://doi.org/10.30596/jrab.v18i1.2046

Bellofatto, A. A., \& Besfamille, M. (2021). Tax decentralization notwithstanding regional disparities. Journal of Urban Economics, 123, 103346. https://doi.org/10.1016/j.jue.2021.103346

Bungin, B. (2017). Metodologi Penelitian Kualitatif(B. Bungin (ed.); 3rd ed.). RajaGrafindo Persada. https://www.rajagrafindo.co.id/produk/metodologi-penelitian-kualitatif-burhan-bungin/

Creswell, J. W. (2017). Research Design Pendekatan Kualitatif, Kuantitatif, dan Mixed (S. Z. Qudsy (ed.); 3rd ed.). Pustaka Pelajar. https:/ / opac.perpusnas.go.id/DetailOpac.aspx?id=1213690

Cyan, M. R., Koumpias, A. M., \& Martinez-Vazquez, J. (2017). The effects of mass media campaigns on individual attitudes towards tax compliance; quasi-experimental evidence from survey data in Pakistan. Journal of Behavioral and Experimental Economics, 70, 10-22. https://doi.org/10.1016/j.socec.2017.07.004

Dewanti, Y. R. (2021). Analisis Efektifitas dan Kontribusi Pemungutan Pajak Reklame Terhadap Pendapatan Asli Daerah di Provinsi DKI Jakarta Tahun 2016-2019. Jurnal Akuntansi Bisnis (JAB), 7(1), 67-76. http://www.journal.stie-yppi.ac.id/index.php/JAB/article/view/378

Flach, L., Irlacher, M., \& Unger, F. (2021). Corporate taxes and multi-product exporters: Theory and evidence from trade dynamics. Journal of International Economics, 132, 103515. https://doi.org/10.1016/j.jinteco.2021.103515

Hadi, S. S. (2021). Analisis Efektivitas Pajak Hotel dan Kontribusi Terhadap Pajak Daerah Pada Badan Pajak dan Retribusi Daerah (BPRD) Propinsi DKI Jakarta. Jurnal Akrab Juara, 6(3), 184-204. https://akrabjuara.com/index.php/akrabjuara/article/view/1537

Hanis, R., \& Saputra, U. (2019). Efektivitas dan Kontribusi Pajak Reklame Dalam Meningkatkan Pendapatan Asli Daerah Kota Pontianak. Jurnal Ekonomi Fakultas Ekonomi Dan Bisnis Universitas Riau, 27(1), 37-46. https://doi.org/http://dx.doi.org/10.31258/je.27.1.p.37-46

Hasibuan, A. A. (2020). Strategi Pemungutan Penerimaan Pajak Reklame Dalam Rangka 
Strategy of Advertising Tax Collection in the Digitalization Era on Badan Pendapatan Daerah of DKI Jakarta

Rofiyanti, Lestari, Davronov, Natision, Krishantoro

Meningkatkan Pendapatan Asli Daerah Kota Medan. Jurnal Karya Ilmiah Fakultas Sosial Sains Universitas Pancabudi, 2(2), 1-81.

https://jurnal.pancabudi.ac.id/index.php/jurnalfasosa/article/view/2280

Karo, L. N. D., Kalangi, L., \& Budiarso, N. S. (2019). Analisis Upaya Pajak, Efektivitas, dan Kontribusi Pajak Daerah di Kawasan Ekonomi Khusus Pada Badan Pengelola Pajak dan Retribusi Daerah Kota Bitung. Jurnal Riset Akuntansi Going Concern, 14(4), 318-326. https://doi.org/10.32400/gc.14.4.26081.2019

Konfino, J., De Maio, F., Ondarsuhu, D., Goldberg, L., Linetzky, B., \& Ferrante, D. (2015). The sociodemographic patterning of opposition to raising taxes on tobacco and restricting tobacco advertisements in Argentina. Public Health, 129(4), 364-369. https://doi.org/10.1016/j.puhe.2014.12.020

Koumpias, A. M., \& Martinez-Vazquez, J. (2019). The impact of media campaigns on tax filing: quasi-experimental evidence from Pakistan. Journal of Asian Economics, 63, 33-43. https://doi.org/10.1016/j.asieco.2019.05.002

Lidyawati, L. (2021). Pengaruh Pajak Hiburan, Pajak Restoran dan Pajak Reklame Terhadap Kinerja Keuangan Pemerintah Daerah Provinsi Dki Jakarta. Jurnal Penelitian Akuntansi Goodwill, 3(1), 252-269. http://jurnal.mputantular.ac.id/index.php/gw/article/view/505

Mardiasmo. (2016). Perpajakan (Mardiasmo (ed.); III). Andi. http:/ /www.library.usd.ac.id/web/index.php?pilih=search\&p=1\&q=0000133697\&go=Det ail

Moleong, L. J. (2018). Metodologi Penelitian Kualitatif (38th ed.). Remaja Rosdakarya. https:/ / opac.perpusnas.go.id/DetailOpac.aspx?id=1133305

Muhaimin, M., Adzim, F., \& Firmansyah, F. (2019). Analisis Potensi Pajak Reklame Terhadap Pendapatan Asli Daerah di Kota Makassar. Amnesty: Jurnal Riset Perpajakan, 2(2), 53-58. https://doi.org/10.26618/jrp.v2i2.2535

Mulatsih, Kusumawardani, A., \& Utomo, R. B. (2021). Analisis Efektivitas, Kontribusi dan Laju Pertumbuhan Pajak Parkir dan Pajak Reklame Terhadap Pendapatan Asli Daerah Provinsi DKI Jakarta Tahun 2016-2020. Jurnal Ilmiah Manajemen Ekonomi Dan Akuntansi, 5(3), 31483165. https://doi.org/https://doi.org/10.31955/mea.vol5.iss3.pp3148-3165

Muspirawati, Iskandar, \& Utomo, R. P. (2021). Analisis Penerimaan Pajak Reklame. Jurnal Ilmu Akuntansi Mulawarman, 6(4), 1-11.

https://doi.org/http://dx.doi.org/10.29264/jiam.v6i4.6617

Neni, L., Nurlela, \& Karlina, L. (2021). Analisis Efektifitas Penerimaan Pajak Reklame dan Kontribusinya Terhadap Pendapatan Asli Kota Medan. Jurnal Ilmiah BISMA Cendekia, 1(2), 67-74. https://www.ojs.politeknikcendana.ac.id/index.php/bisma/article/view/35

Octaviany, F., Rustanto, A. E., \& Kartini, I. (2021). Analisis Pelayanan Pajak Dalam Meningkatan Pendapatan Asli Daerah (PAD) di Wilayah Kota Jakarta Utara. Jurnal Reformasi Administrasi, 8(1), 10-21. https://doi.org/https://doi.org/10.31334/reformasi.v8i1.1415

Ratnaningsih, D., \& Waluyo, W. (2019). Analisis Faktor-faktor yang Mempengaruhi Kepatuhan Pajak Reklame Pada Dinas Pelayanan Pajak Daerah Provinsi DKI Jakarta. Jurnal Informasi, Perpajakan, Akuntansi, Dan Keuangan Publike, 12(2), 83.

https://doi.org/10.25105/jipak.v12i2.5113

Rolamdo, J., \& Widiastuti, N. P. E. (2021). Efektivitas Pengendalian Internal Pemungutan Pajak Reklame pada Unit Pelayanan Pemungutan Pajak Daerah Kelapa Gading. Perspektif 
Strategy of Advertising Tax Collection in the Digitalization Era on Badan Pendapatan Daerah of DKI Jakarta

Rofiyanti, Lestari, Davronov, Natision, Krishantoro

Akuntansi, 4(3), 255-276. https://doi.org/10.24246/persi.v4i3.p255-276

Safitri, I. I. (2021). Analisis Terhadap Kontribusi Pajak Reklame, Pajak Hotel dan Pajak Restoran Dalam Meningkatkan Pendapatan Asli Daerah (PAD) Pada Badan Pendapatan Daerah DKI Jakarta. Jurnal Akuntansi Dan Manajemen (JAM), 18(1), 76-83. https://doi.org/https://doi.org/10.36406/jam.v18i01.350

Seip, K. L. (2019). Does tax reduction have an effect on gross domestic product? An empirical investigation. Journal of Policy Modeling, 41(6), 1128-1143. https://doi.org/10.1016/j.jpolmod.2019.01.005

Song, M., Wang, S., \& Zhang, H. (2020). Could environmental regulation and R and D tax incentives affect green product innovation? Journal of Cleaner Production, 258, 120849. https://doi.org/10.1016/j.jclepro.2020.120849

Sugiyono. (2019). Metode Penelitian Kuantitatif Kualitatif dan R\&D (I). Alfabeta. https://cvalfabeta.com/product/metode-penelitian-kuantitatif-kualitatif-dan-rd-mpkk/

Wulandari, T. R., Adiati, A. K., \& Paravitasari, D. (2017). Analisis Pajak Reklame di Kabupaten Purworejo Periode 2012-2016. Jurnal Akuntansi Dan Pajak, 18(01), 1-18. https://doi.org/10.29040/jap.v18i01.94 